\title{
Evaluation of the antioxidant activity of extracts and flavonoids obtained from Bunium alpinum Waldst. \& Kit. (Apiaceae) and Tamarix gallica L. (Tamaricaceae)
}

\author{
Mostefa Lefahal ${ }^{1}$, Nabila Zaabat ${ }^{1}$, Lakhdar Djarri ${ }^{1}$, Merzoug Benahmed ${ }^{2}$, \\ Kamel Medjroubi ${ }^{1}$, Hocine Laouer ${ }^{3}$, Salah AkKal ${ }^{1 \star}$
}

\begin{abstract}
${ }^{1}$ Université de Constantine 1, Unité de Recherche Valorisation des Ressources Naturelles Molécules Bioactives et Analyses PhysicoChimiques et Biologiques, Département de Chimie, Facultés des Sciences Exactes, Algérie

${ }^{2}$ Université Larbi Tébessi Tébessa Laboratoire des Molécules et Applications, Algérie

${ }^{3}$ Université Ferhat Abbas Sétif 1, Laboratoire de Valorisation des Ressources Naturelles Biologiques. Le Département de Biologie et d'écologie Végétales, Algérie
\end{abstract}

\begin{tabular}{l}
\hline ARTICLE INFO \\
\hline Received 19 October 2016 \\
Accepted 24 January 2017 \\
\hline Keywords: \\
B. alpinum, \\
T. gallica, \\
flavonoids, \\
antioxidant activity, \\
DPPH assay, \\
EC $_{50}$
\end{tabular}

\begin{abstract}
The aim of the present work was to evaluate the antioxidant activity of extracts and four flavonoids that had been isolated from the aerial parts of Bunium alpinum Waldst. et Kit. (Apiaceae) and Tamarix gallica L. (Tamaricaceae). In this work, the four flavonoids were first extracted via various solvents, then purified through column chromatography (CC) and thin layer chromatography (TLC). The four compounds were subsequently identified by spectroscopic methods, including: UV, mass spectrum ${ }^{1} \mathrm{H}$ NMR and ${ }^{13} \mathrm{C}$ NMR. The EtOAc extract of Bunium alpinum Waldst. et Kit yielded quercetin-3-O- $\beta$-glucoside (3',4',5,7-Tetrahydroxyflavone-3- $\beta$-D-glucopyranoside) (1), while the EtOAc and n-BuOH extracts of Tamarix gallica L. afforded 3,5,3'-trihydroxy-7,4'-dimethoxyflavone (2), 3,5,7-trihydroxy-4'-methoxyflavone (3) and 5-hydroxy-3,7,4'-trimethoxyflavone (4).

The antioxidant activity of the extracts and the flavonoids were then evaluated through DPPH free radical-scavenging assay. Of all studied extracts, the n-Butanol extract of Bunium alpinum $\left(\mathrm{EC}_{50}=1.84 \mu \mathrm{g} / \mathrm{ml}\right)$ showed the best antioxidant activity against (DPPH). In contrast, the isolates demonstrated varying degrees of antioxidant activity: compound (1) was the more active $\left(\mathrm{EC}_{50}=0.28 \mu \mathrm{g} / \mathrm{ml}\right.$ ), followed by compound (3) and (2) $\left(\mathrm{EC}_{50}=0.309 \mu \mathrm{g} / \mathrm{ml}, \mathrm{EC}_{50}=0.406 \mu \mathrm{g} / \mathrm{ml}\right.$, respectively), compound (4) showed the lowest activity. All the isolated flavonoids exhibited antioxidant activity, but this was lower than the control (Trolox). In conclusion, due to the presence of flavonoids in their ariel parts, the studied plants could be natural sources of several important antioxidant agents.
\end{abstract}

\section{INTRODUCTION}

In modern medicine, herbal remedies still make a significant contribution to health care, being the origin source of most drugs. In this context, several researches continue to study plants which could be the source of novel remedies.

The genus Bunium (Apiaceae) involves about 50 to 100 species in the world, which are frequently distributed in: Algeria, Italy, Pakistan, Iran and South Africa. In the Algerian flora, this genus includes seven species, four of which are endemic [24]. Due to their medicinal and nutriment benefits, several species of this genus are often used

\footnotetext{
* Corresponding author

e-mail: salah4dz@yahoo.fr
}

in folk medicine; for example, the species Bunium persicum is generally employed as a antispasmodic, a carminative, an anti-obesity and a lactogage [27]. Furthermore, the fruits of this plant are employed in treating digestive and urinary system complaints, while the seeds have some important effects as hypoglycemics, anticonvulsants and antiemetics [14]. Several researches have shown that the essential oil and the extracts from some Bunium species have antihistaminic, antfungal, antibacterial [8] and antioxidant activities [26]. Indeed, phytochemical studies on the genus Bunium have revealed the presence of coumarins [5,9] and sesquiterpenes [4], while, especially, the essential oil (monoterppenoids) is seen as a source of metabolites [25]. Of note: it has been 
documented that in Algeria, the roots of Bunium incrassatum are usually eaten as a potato substitute [9].

The genus Tamarix L. (Tamaricaceae) is represented in Algeria by ten species [24]. Several species of this genus are employed in folk medicine as astringents, aperitifs, as stimuli of perspiration and as diuretics. Moreover, in Algeria and surrounding areas, some species are used to treat rheumatism and diarrhea [11]. In addition, some Tamarix species (Tamarix ramosissima and Tamarix hispida) have noted antioxidant effects [28] and antibacterial activities (Tamarix gallica) [20]. Furthermore, previous phytochemical investigations have reported that aerial parts of Tamarix species contain lipophilic methylated flavonoids such as: kaempferol-7,4'-dimethylether [13], chrysoeriol, isorhamnetin, rhamnazin [30], tamarixetin [29,30], 7,3',4'-trihydroxy-5-methoxyflavone, 3,7,4'-trihydroxy-5-meth-oxyflavone, 3,5,7-trihydroxy-3',4'-dimeth-oxyflavone[31], 7-O-sinapoylKaem-pferide [7]. The objective of the study was to evaluate the antioxidant activity of extracts and four isolated flavonoids obtained from two plants growing in Algeria: Bunium alpinum Waldst. \& Kit (Apiaceae) and Tamarix gallica L. (Tamaricaceae).

\section{MATERIALS AND METHODS}

\section{Plant material}

Aerial parts of Bunium alpinum Waldst. \& Kit (Apiaceae) were collected from Setif (east of Algeria) in May 2012, the plant having been identified by Prof Houcine Laouar (Department of Biology, Setif University, Algeria). While the aerial parts of Tamarix gallica L. (Tamaricaceae) were collected from Tebessa in the east of Algeria in March, 2006. A voucher specimen of each species was deposited in the herbarium of our laboratory.

\section{Extraction and isolation}

Bunium alpinum Waldst. \& Kit (Apiaceae): Air dried aerial parts $(300 \mathrm{~g})$ of plant were firstly extracted three times with $\mathrm{MeOH} / \mathrm{CH}_{2} \mathrm{Cl}_{2}$ (1:1). The extract $\mathrm{MeOH} / \mathrm{CH}_{2} \mathrm{Cl}_{2}$ was evaporated till dryness; the obtained residue was dissolved in water, then filtered. The filtrate was extracted with EtOAc ( $2 \mathrm{~g})$ and n-BuOH (6 g), successively. The EtOAc extract was then chromatographed on silica gel column and eluted with a gradient of EtOAc-MeOH with increasing polarity. Fractions eluted with EtOAc-MeOH 60-40 gave a yellow precipitate, which was washed with $\mathrm{MeOH}$ to offer compound (1) (30 mg).

Tamarix gallica L. (Tamaricaceae): Air dried aerial parts $(500 \mathrm{~g})$ of the plant were extracted three times with boiling $70 \% \mathrm{MeOH}[6]$. The extracted $\mathrm{MeOH}$ was evaporated till dryness, and the residue were dissolved in boiling water, then filtered. The filtrate was subsequently extracted with ethyl acetate EtOAc (9.32 g) and n-BuOH (25.69 g), successively. The EtOAc extract was chromatographed on polyamide MN-SC6 column, and eluted with a gradient of Toluene-MeOH with increasing polarity. Fractions eluted with toluene-MeOH 75-25 gave a yellow precipitate, which was washed by $\mathrm{MeOH}$ to give compound (2) (12.4 mg).
The n-BuOH extract was subjected to a MN-SC6 polyamide column chromatography, being eluted with a gradient of toluene/ $\mathrm{MeOH}$ by increasing polarity. Five main fractions (A, B-G and H) were collected and analyzed via DC6 polyamide TLC, using Toluene: MeCOEt: $\mathrm{MeOH})(4: 3: 3)$ and $\mathrm{H}_{2} \mathrm{O}: \mathrm{MeOH}$ : MeCOEt: Acetylacetone (13:3:3:1) as solvent systems. From fraction B, compound (3) (10 mg) and compound (4) (14 mg) were separated via preparative polyamide TLC, using a Toluene: MeCOEt: $\mathrm{MeOH})(4: 3: 3)$ system as eluent.

\section{Evaluation of antioxidant activity}

Antioxidant activity of the extracts and purified compounds were evaluated with the 1,1-diphenyl-2-picrylhydrazyl (DPPH) assay [17] according to the method described by Brand-William [10]. The molecule DPPH is characterized as being a stable-free radical by virtue of the delocalization of spare electron over the molecule. This delocalization gives a rise to a deep violet color, which is revealed by an absorption band in methanol solution centered at $515 \mathrm{~nm}$ spectrophotoscopically. Five main dilutions of each extract and compound were prepared from the stock solution. These were added at an equal volume to a methanolic solution of $\mathrm{DPPH}$, and the product was then transferred to a 96 well microplate and incubated at room temperature for $30 \mathrm{~min}$. After this, the absorbance was measured at $515 \mathrm{~nm}$. Trolox was used as standard control. The percentage of DPPH remaining was calculated as a function:

$$
\mathrm{DPPH} \%=\left[\left(\mathrm{DO}_{\text {control }}-\mathrm{DO}_{\text {sample }}\right) / \mathrm{DO}_{\text {control }}\right] \times 100
$$

The $\mathrm{EC}_{50}$ value, was defined as the effective concentration of antioxidant that was necessary to decrease the initial DPPH concentration by 50\% [3]. This was calculated from the results through linear regression analysis.

\section{RESULTS AND DISCUSSION}

\section{Structures elucidation}

The isolated compounds were identified by spectral data, as well as: UV-visible, 1H, 13C NMR spectra and mass spectroscopy, their structures (Fig. 1) were confirmed by comparison with literature data.

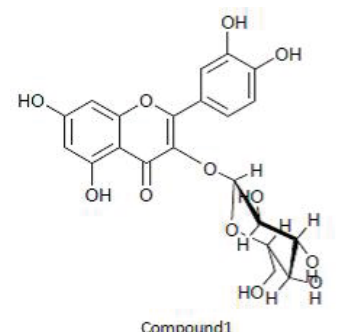<smiles>COc1cc(O)c2c(=O)c(O)c(-c3ccc(OC)c(O)c3)oc2c1</smiles>
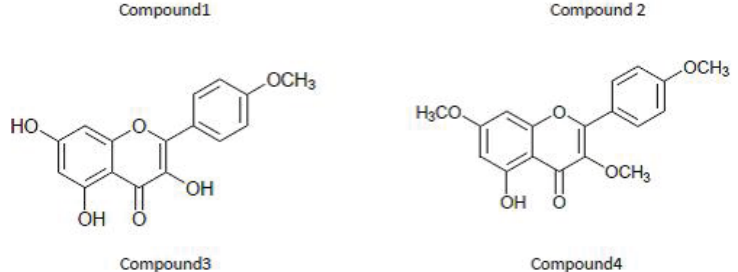
Compound (1): quercetin-3-O- $\beta$-glucoside $\mathrm{C}_{21} \mathrm{H}_{12} \mathrm{O}_{16}$; isolated from an EtOAc extract of Bunium alpinum Waldst. $\&$ Kit (Apiaceae) as a yellow powder;

$\mathrm{UV}_{\lambda \max }(\mathrm{MeOH}) \mathrm{nm}: 271-357,+\mathrm{NaOH} ; 411,275 ;+\mathrm{AlCl}_{3}$; 426, 273; $+\mathrm{AlCl}_{3} / \mathrm{HCl} ; 402,268 ;+\mathrm{CH}_{3} \mathrm{COONa} ; 366,260$. Mass spectrum (ESI+-MS): 487[M+Na] ${ }^{+}, 303[\mathrm{M}-162+\mathrm{H}]$, ${ }^{1} \mathrm{H}-\mathrm{NMR}$ (300 MHz, DMSO-d6, $\delta$ in ppm) data: $6.21(1 \mathrm{H}, \mathrm{d}$, $\mathrm{J}=2 \mathrm{~Hz}, \mathrm{H}-6), 6.42$ (1H, d, J = $2 \mathrm{~Hz} \mathrm{H}-8), 6.84$ (1H, d, $\left.\mathrm{J}=8.5 \mathrm{~Hz}, \mathrm{H}-5^{\prime}\right), 7.54$ (1H, d, J = 2 Hz, H-2'), 7.70 (1H, dd, $\mathrm{J}=8.5-2 \mathrm{~Hz}, \mathrm{H}-6$ '), 12.69 (1H, s, H-5), $5.41(1 \mathrm{H}, \mathrm{d}, \mathrm{J}=7.6 \mathrm{~Hz}$, $\mathrm{H}-1$ "), sugar protons $(3.5-4, \mathrm{~m})$.

${ }^{13} \mathrm{C}-\mathrm{NMR}$ (75 MHz, DMSO-d6, $\delta$ in ppm) data: 156.25 (C-2), 133.4 (C-3), 177.4 (C-4), 161.1 (C-5), 98.6 (C-6), 164.0 (C-7), 93.5 (C-8), 156.2 (C-9), 103.8 (C-10), 101.7 (C-1'), 115.1 (C-2'), 144.7 (C-3'), 148.4 (C-4'), 115.9 (C-5'), 121.8 (C-6'), 101.7 (C-1"), 71.1 (C-2”), 73.0 (C-3"), 67.86 (C-4”), 75.7 (C-5”), 60.0 (C-6”) [12].

Compound (2): 3',3,5-trihydroxy-4',7-diméthoxyflavone $\mathrm{C}_{17} \mathrm{H}_{14} \mathrm{O}_{7}$ : isolated from an EtOAc extract of Tamarix gallica L. (Tamaricaceae) as a yellow powder.

$\mathrm{UV}_{\lambda \max }(\mathrm{MeOH}) \mathrm{nm}: 370,252,+\mathrm{NaOH} ; 398,275 ;+\mathrm{AlCl}_{3}$; 419, 254, 246; $+\mathrm{AlCl}_{3} / \mathrm{HCl} ; 418,254,246 ;+\mathrm{CH}_{3} \mathrm{COONa}$; 371, 271. Mass spectrum (ESI+-MS): 353[M+Na] +, ${ }^{1} \mathrm{H}-\mathrm{NMR}(300 \mathrm{MHz}, \mathrm{MeOH}-\mathrm{d} 4, \delta$ in ppm) data: $6.16(1 \mathrm{H}, \mathrm{d}$, $\mathrm{J}=2.5 \mathrm{~Hz}, \mathrm{H}-6), 6.49(1 \mathrm{H}, \mathrm{d}, \mathrm{J}=2.5 \mathrm{~Hz} \mathrm{H}-8), 7.15(1 \mathrm{H}, \mathrm{d}$, $\left.\mathrm{J}=8.6 \mathrm{~Hz}, \mathrm{H}-5^{\prime}\right), 7.75$ (1H, d, J = 2.5 Hz, H-2'), 7.78 (1H, dd, $\mathrm{J}=8.6-2.5 \mathrm{~Hz}, \mathrm{H}-6$ '), 12.69 (1H, s, H-5), 3.83, 3.84 (6H, s, 2-OCH3), ${ }^{13} \mathrm{C}-\mathrm{NMR}$ (75 MHz, DMSO-d6 $\delta$ in ppm) data: 176.6 (C-4), 166.7 (C-7), 161.6 (C-9), 157.7 (C-5), 150.2 (C-4'), 147.2 (C-3'), 146.8 (C-2), 137.2 (C-3), 124.7 (C-1'), 121.2 (C-6'), 115.1 (C-2'), 112.1 (C-5'), 104.8 (C-10), 98.4 (C-6), 92.7 (C-8), 56.4 (3'-OCH3), 56.3 (7'-OCH3), [18,32].

Compound (3): 3,5,7-Trihydroxy-4-methoxyflavone $\mathrm{C}_{16} \mathrm{H}_{12} \mathrm{O}_{6}$; isolated from a n-Butanol extract of Tamarix gallica L. (Tamaricaceae) as a yellow crystal.

UV spectrum (MeOH, $\lambda_{\text {max }}$ in $\left.\mathrm{MeOH}\right) 261,363 \mathrm{~nm}$; $\mathrm{NaOH}: 275,390$; +AlCl3: 269, 425; +AlCl3/HCl: 270 , 426-421; + $\mathrm{CH}_{3} \mathrm{COONa:} 269$, 370. Mass spectrum (EI, 70ev, m/z): 300[M]+, 285[M-15]+, 257[M-15-28]+, ${ }^{1} \mathrm{HNMR}$ spectrum $\left(250 \mathrm{MHz}, \mathrm{MeOH}-\mathrm{d}_{4}, \delta\right.$ in ppm) data: $6.20(1 \mathrm{H}, \mathrm{d}$, $\mathrm{J}=2 \mathrm{~Hz}, \mathrm{H}-6), 6.42$ (1H, d, J = 2Hz, H-8), 7.1(2H, d, J = 7.9 Hz, H-3, H-5'), 8.16 (2H, d, J = 7.9 Hz, H-2', H-6), 3.91 $(3 \mathrm{H}, \mathrm{s},-\mathrm{OCH} 3),{ }^{13} \mathrm{C}-\mathrm{NMR}(75 \mathrm{MHz}, \mathrm{DMSO}-\mathrm{d} 6 \delta$ in ppm) data:146.3 (C-2), 136.1 (C-73), 176.1 (C-4), 160.8 (C-5), 98.3 (C-6), 164.1 (C-7), 93.6 (C-8), 156.3 (C-9), 103.7 (C-10), 123.3 (C-1'), 129.4 (C-2'), 114.1 (C-3'), 160.6 (C-4'), 114.1 (C-5'), 129.4 (C-6'), 55.4 (4'-OCH3) [15].

Compound (4): 5-Hydroxy-3,7,4-tri-methoxyflavone $\mathrm{C}_{18} \mathrm{H}_{16} \mathrm{O}_{6}$; isolated from a n-Butanol extract of Tamarix gallica L. (Tamaricaceae) as a white powder.

$\mathrm{UV}\left(\lambda_{\max }\right.$ in $\left.\mathrm{MeOH}\right): 344,268 \mathrm{~nm} ; \mathrm{NaOH} ; 360,275 \mathrm{~nm}$; $+\mathrm{AlCl}_{3}$; 396, 346, $276 \mathrm{~nm}$; $+\mathrm{AlCl}_{3} / \mathrm{HCl}: 396,350,276 \mathrm{~nm}$; $+\mathrm{CH}_{3} \mathrm{COONa} ; 346,269 \mathrm{~nm}$. Mass spectrum (EI, 70ev, m/z): $330[\mathrm{M}+\mathrm{H}+1]+, 314[\mathrm{M}+\mathrm{H}-15]+, 300[\mathrm{M}-28]+, 285[\mathrm{M}-28-$ $15]+,{ }^{1} \mathrm{HNMR}$ spectrum (250 MHz, DMSO-d6, $\delta$ in ppm) data: 6.25 (1H, d, J = 2Hz, H-6), 6.42 (1H, d, J = 2 Hz, H-8), $7(2 \mathrm{H}, \mathrm{d}, \mathrm{J}=9 \mathrm{~Hz}, \mathrm{H}-3, \mathrm{H}-5), 8.25(2 \mathrm{H}, \mathrm{d}, \mathrm{J}=9 \mathrm{~Hz}, \mathrm{H}-2, \mathrm{H}-6)$, 3.84- 3,88(9H, s,-OCH3). ${ }^{13} \mathrm{C}-\mathrm{NMR}$ (75 MHz, DMSO-d6 $\delta$ in ppm) data: 156.7 (C-2), 138.5 (C-73)176.1(C-4), 161.2 (C-5), 98.0 (C-6), 166.0 (C-7), 92.2 (C-8), 157.0 (C-9),
104.0 (C-10), 122.6 (C-1'), 129.9 (C-2'), 114.0 (C-3'), 161.9 (C-4'), 114.0 (C-5'), 129.9 (C-6'), 59.5 (3'- OCH $\left._{3}\right), 55.9$ $\left(7-\mathrm{OCH}_{3}\right), 55.5\left(4^{\prime}-\mathrm{OCH}_{3}\right)[1]$.

\section{The antioxidant activity}

The antioxidant (DPPH scavenging) activity of extracts and flavonoids of the two plants was evaluated through the ability to scavenge DPPH free radicals. Parameter $\mathrm{EC}_{50}$ is defined as the effective concentration of antioxidant that are necessary to decrease the initial DPPH concentration by $50 \%$. In this regard, the lower value of $\mathrm{EC}_{50}$ associates with the higher antioxidant potential [22]. The antioxidant activity of the two plant extracts are given in (Tab. 1). All extracts from the two plants showed antioxidant activity, but the n-Butanol extract of Bunium alpinum was the most effective $\left(\mathrm{EC}_{50}=1.84 \mu \mathrm{g} / \mathrm{ml}\right)$. The antioxidant activity of these extracts may be linked to the presence of flavonoids in their compositions. The antioxidant activities of the isolated flavonoids are shown in (Tab. 2). The derived antioxidant activity increased in the following order: compound (4) < compound (2) < compound (3) < compound (1).

The evaluation of antioxidant activity by the DPPH method uncovered a large difference among the investigated flavonoids. This may be associated with differences in their structures. In this regard, compound (1) flavone,5,7,3',4'tetrahydroxy-3-beta-D-glucopyranoside, $\mathrm{EC}_{50}=0.28 \mu \mathrm{g} / \mathrm{ml}$ ), which was isolated from Bunium Alpinum, showed a greater antioxidant activity than did the other isolated flavonoids. Such a difference may be explained by the presence of polyhydroxylated groups on the ring B. Indeed, Gordana et al. suggested that the presence of polyhydroxylated groups in the B ring increase antioxidant activity [16]. Furthermore, the higher antioxidant activity of compound (1) can also be attributed to the 3',4'-catechol structure in the ring B [21]. Among the three flavonoids isolated from Tamarix gallica L.; compound (3) (3,5,7-trihydroxy-4'-methoxyflavone $\mathrm{EC}_{50}=0.309 \mu \mathrm{g} / \mathrm{ml}$ ) was the most active, while, compound (4) (5-hydroxy-3,7,4'-trimetoxyflavone, $\mathrm{EC}_{50}=0.725 \mu \mathrm{g} / \mathrm{ml}$ ) exhibited the lowest scavenging activity.

Table 1. Antioxidant activity of extracts

\begin{tabular}{|l|c|c|}
\hline & Extract & $\mathrm{EC}_{50}(\mu \mathrm{g} / \mathrm{ml})$ \\
\hline \multirow{3}{*}{ B. alpinum } & $\mathrm{MeOH}: \mathrm{CH}_{2} \mathrm{Cl}_{2}$ & 2.89 \\
& $\mathrm{AcOEt}$ & 2.11 \\
& $\mathrm{n}-\mathrm{BuOH}$ & 1.84 \\
\hline \multirow{2}{*}{ T. gallica } & $\mathrm{MeOH}$ & 3.89 \\
\hline Standard & AcOEt & 2.66 \\
\hline
\end{tabular}

Table 2. Antioxidant activity of isolated flavonoids

\begin{tabular}{|l|c|c|}
\hline & flavonoids & $\mathrm{EC}_{50}(\mu \mathrm{g} / \mathrm{ml})$ \\
\hline B. alpinum & compound (1) & 0.28 \\
\hline \multirow{2}{*}{ T. gallica } & compound (2) & 0.406 \\
& compound (3) & 0.309 \\
\hline \multirow{2}{*}{ Standard } & compound (4) & 0.725 \\
\hline
\end{tabular}

The weak activity showed by compound (4) could be linked to the substitution of this flavonoid by various number of OMe groups. This observation is in agreement with the earlier study of Jeong et al., who found that the substitution of flavonoids by various numbers of OMe groups decreased 
antioxidant activity [19]. In addition, it appears that the presence of 3-OH groups in the structures of flavonoids compound (2) and (3) increase significantly the antioxidant activity when compared to that with 3-OMe groups of compound (4). This observation is in accordance with that of Op de Beck et al. [23] and with that of Amic et al., who confirmed that the presence of 3-OH groups significantly enhances antioxidant activity [2]. All the flavonoids isolated from the two plants showed antioxidant activity, but less than the Trolox used as control $\left(\mathrm{EC}_{50}=0.106 \mu \mathrm{g} / \mathrm{ml}\right)$.

\section{CONCLUSION}

The present study reported the antioxidant activity of extracts, as well as that of four flavonoids isolated from the aerial parts of Bunium alpinum Waldst. \& Kit (Apiaceae) and Tamarix gallica L. (Tamaricaceae). The findings of this study reveal that Bunium alpinum Waldst. \& Kit and Tamarix gallica L. have potential to be used as natural antioxidant agents. This study, hence, suggests that further research be taken so as to ascertain the other pharmacological potential of these species.

\section{ACKNOWLEDGMENTS}

The Ecologie Microbienne, CESN, ISPB, 8 Avenue Rockefeller, F69373 Lyon cedex, France is acknowledged for the biological activities facilities.

\section{CONFLICTS OF INTEREST}

The authors declare no conflict of interest.

\section{REFERENCES}

1. Al-Oqail M. et al.: Phytochemical and biological studies of Solanum schimperianum Hochst. Saudi Pharmaceutical Journal, 20, 2012.

2. Amic D., Beslo D., Trinajstic N.: Structure-Radical scavenging activity relationships of flavonoids. Croatica Chemica Acta, 76, 1, 2003.

3. Apak R. et al.: Methods of measurement and evaluation of natural antioxidant capacity/activity (IUPAC Technical Report). Pure Appl Chem., 85, 5, 2013.

4. Appendino G. et al.: A Sesquiterpene Ketal from Bunium Paucifolium. Phytochemistry, 30, 10, 1991.

5. Appendino G., Ozent H.C., Jakupovic J.: Prenylated Isocoumarins from Bunium Paucifolium. Phytochemistry, 36, 2, 1994.

6. Azzouzi S. et al.: Phytochemical and biological activities of Bituminaria bituminosa L. (Fabaceae). Asian Pacific Journal of Tropical Biomedicine, 4, 1, 2014.

7. Bikbulatova T.N., Korul'Kina L.M.: Composition of Tamarix hokenakeri and T. ramosissima. Chemistry of Natural Compounds, 37, 3, 2001.

8. Boskabady M.H., Moghaddas A.: Antihistaminis Effect of Bunium persicum on Guinea Pig Tracheal Chains. Iranian Biomedical Journal, 3, 8, 2004.

9. Bousetla A. et al.: Chemical constituents of the roots of Algerian Buniumin incrassatum and evaluation of its antimicrobial activity. Arabian Journal of Chemistry, 8(3), 313, 2015.
10. Brand W.W., Cuvelier M.E., Berset C.: Use of a free radical method to evaluate antioxidant activity. WT-Food Sci Technol., 28, 1, 1995.

11. Chaturvedi S., Drabu S., Sharam M.: Antiinflammatory and analgesic activity of Tamarix gallica. International Journal of Pharmaceutical Sciences, 4, 3, 2012.

12. Eldahshan O.A. et al.: Potential Superoxide Anion Radical Scavenging Activity of Doum Palm (Hyphaene thebaica L.) Leaves Extract. Records of Natural Products, 2, 3, 2008.

13. El-Sissi H.I., Newark M.A.M., Saleh N.A.M.: Plant constituents of Tamarix nilotica leaves (Tamaricaceae)., Experientia, 29, 1973.

14. Emamipoor Y., Maziah M.: An efficient method in breaking of dormancy from Bunium persicum (Boiss) Fedtsch seeds: A valuable herb of Middle East and Central Asia. Asian Pacific Journal of Tropical Biomedicine, 4, 8, 2014.

15. Eunjung L. et al.: Effects of Hydroxy and Methoxy Substituents on NMR Data in Flavonols. Bull. Korean Chem. Soc., 29, 2, 2008.

16. Gordana R., Herzwig O.G., Jutta L.M.: Structurally related flavonoids with antoxidative properties differentially affect cell cycle progression and apoptosis of human acute lezukmia cells. Nutrition Research., 25, 2005.

17. Harkati B. et al.: Evaluation of antioxidant activity, free radical scavenging and CUPRAC of two compounds isolated from Scorzonera undulatessp deliciosa. Advances in Environmental Biology, 7, 4, 2013.

18. Huong D.T. et al.: A new flavone and cytotoxic activity of flavonoid constituents isolated from Miliusa balansae (Annonaceae). Pharmazie, 60, 2005.

19. Jeong J.M. et al.: Antioxidant and Chemosensitizing Effects of Flavonoids with Hydroxy and/or Methoxy Groups and StructureActivity Relationship. J Pharm Pharmaceut Sci., 10, 4, 2007.

20. Lafhal M. et al.: Antimicrobial Activity of Tamarix gallica L. Extracts and Isolated Flavonoids. Advances in Natural and Applied Sciences, $4,3,2010$.

21. Menga Q. et al.: Free radical scavenging activity of Eagle tea and their flavonoids. Acta Pharmaceutica Sinica B., 2, 3, 2012.

22. Mihai C.M., Marghitas L.A.: Antioxidant Capacity of Transylvanian Propolis. Bulletin UASVM Animal Science and Biotechnologies, 67, 1-2, 2010.

23. Op de Beck P. et al.: Antioxidant Flavonoids and Phenolic Acids from Leaves of Leea guineense G. Don (Leeaceae). Phytotherapy Research, 17, 2003

24. Quezel P. (1963). Nouvelle flore de l'Algérie et des régions désertiques et Méridionales. Centre National de la Recherche Scientifique. Paris, pp. 678-690.

25. Salehi P., Mohammadi F., Asghari B.: Seed essential oil analysis of Bunium persicum by hydrodistilation-headspace solvent microextraction. Chemistry of Natural Compounds, 44, 111, 2008.

26. Shahsavari N., Barzegar M., Sahari M.A.: Antioxidant Activity and Chemical Characterization of Essential Oil of Bunium persicum. Plants Foods for Human Nutrition, 63, 4, 2008.

27. Sharififar F., Yassa N., Mozaffarian V.: Bioactivity of major components from the seeds of Bunium persicum (Boiss.) Fedtch. Pak J Pharm Sci., 23, 300, 2010.

28. Sultanova N. et al.: Isotamarixen - a new antioxidant and prolyl endopeptidase-inhibiting triterpenoid from Tamarix hispida. Planta Med., 70, 1, 2001.

29. Sultanova N. et al.: Antioxidant and antimicrobial activities of Tamarix ramosissima. Journal of Ethnopharmacology, 78, 201, 2001.

30. Umbetova A.K. et al.: Flavonoids of plants from the genus Tamarix. Chemistry of Natural Compounds, 40, 3, 2004.

31. Umbetova A.K. et al.: Flavonoids of plants from the genus Tamarix. Chemistry of Natural Compounds, 41, 6, 2005.

32. Zhao Y.L. et al.: Cytotoxic Constituents of Viscum coloratum. Z. Naturforsch., 67c, 2012. 